\title{
TECHNICAL EFFICIENCY DIFFERENTIALS IN OIL PALM PROCESSING TECHNOLOGIES IN CROSS RIVER STATE, NIGERIA
}

\author{
Zakari Abdulsalam, James Asu Nandi and Ben Ahmed
}

\begin{abstract}
This research analyzed technical efficiency differentials between traditional and improved oil palm processing technologies in Cross River State, Nigeria. A multistage sampling technique was used to select 164 processors. Data were collected through questionnaire and analysed using stochastic frontier. Results revealed mean efficiency of $62 \%$ for traditional and $81 \%$ for improved technologies. Implying that, no need for the development of a new technology; however, production can be improved using current available technologies. Labour, fresh fruit, depreciation cost and other variables costs were found to affect technical efficiency of traditional processors positively while labour, fresh fruit and other variables costs positively affect improved technologies users' technical efficiency. Determinants of technical efficiency for both groups of processors were processing experience, educational level and access to extension contact. It was recommended that adoption of improved technologies for processing oil palm should be encouraged by government through extension service and credit facilities.
\end{abstract}

Keywords: determinants, differentials, stochastic frontier, technologies,

\section{INTRODUCTION}

Prior to the commercial exploration of petroleum in Nigeria, the agricultural sector was the leading contributor to the economy. According to Ugwu (2009), before independence, Nigeria was a major exporter of agricultural commodities such as palm oil, cocoa, groundnut, cotton and rubber. Now, Nigeria is a net importer of palm oil and its products, whereas, between 1961 and 1965, Nigeria was the largest producer of palm oil, accounting for 43 percent of the world production (Olagunju, 2008). However, since then, oil palm production in Nigeria has virtually been decreasing. In the early 90 s, Nigeria accounted for 7 percent of the world production (WRM, 2001; Olagunju, 2008; Oladipo, 2008), in 2004, it was 3 percent, while in 2010; Nigeria produced 2.2 percent of palm oil and 9.4 percent of palm kernel (FAOSTAT, 2010). Nwajiuba and Akinsami (2003) noted that the contribution of oil palm as an export and foreign exchange earner started declining as Nigeria petroleum earnings escalated, drawing labour away from the rural farm sector to the urban non-farm sector.

The domestic and industrial demands for oil palm produce globally continue to be on the increase. Vogel (2002) estimated that for every five people in Nigeria, perhaps two liters of palm oil or more are consumed each month for cooking. Therefore, the demand for oil palm products has far outstripped supply; a scenario that is assumed would further push prices up over time. With increasing population, growth rate and improvement in purchasing power of Nigerians, the market keeps growing. The emerging capability for more sophisticated products by the local food industry may in fact widen the gap between demand and supply for oil palm products. 
To foster research and bridge the demandsupply gap in oil palm sub-sector, Nigeria Institute for Oil Palm Research (NIFOR) aimed at improving oil palm production and processing through technological advancement, in areas such as generating hybrid varieties and processing technologies which can reduce losses and obtain higher extraction rate (Aghalino, 2000; Aliu, 2010). Now, within the African continent, Nigeria is the country having more extensive oil palm plantations, with at least 350,000 hectares planted to this crop (WRM, 2000). Yet, processed oil palm products continue to decrease in quantity. This has been attributed to losses encountered during processing (Orewa, 2009).

In order to revitalize the oil palm sub-sector to improve the standard of living of the rural populace that depend on this produce for their livelihood, processors were encouraged to move away from traditional oil palm processing technologies to improved technologies. These improved processing technologies such as threshers, digesters, motorized press, sterilizers, and clarifiers were developed and introduced to the processors (Agwu, 2006); in view of the fact that the bottleneck in palm oil processing is crude processing techniques. Despite the huge investment and research efforts at developing these improved methods, most processors still use the traditional processing techniques, thereby, casting doubts to the efficacy of the improved processing technologies.

Apart from food which oil palm products are known for, palm oil production provides jobs for at least 1.8 million Nigerians (Ayodele, 2010); and serve as a major source of income to a large proportion of the resource poor rural processors in Nigeria (Olagunju, 2008). In spite of the great potentials of oil palm processing in Nigeria, the efficiency or inefficiency of utilization of available resources has remained an unanswered question in the quest for increased output. Knowing that, the concept of efficiency is concerned with the relative performance of the processes used in transforming given inputs into outputs. A production process that uses more physical resources than an alternative method in producing a unit of output is thus, said to be technically inefficient. Technical efficiency as defined by Heady (1982) is the measure of a firm's success in producing maximum output from a given set of inputs.

Efficiency is a very important factor of productivity growth, especially in developing agricultural economies where resources are meager and opportunities for developing and adopting better technologies are dwindling (Bifarin et al., 2010). In fact, the presence of shortfalls in technical efficiency means that output can be increased without requiring additional conventional inputs or introduction of new technologies. If this is the case, then empirical measures of technical efficiency are necessary in order to determine the magnitude of the gain that could be obtained by improving performance in production with a given technology. Given the foregoing scenario, the study intends to determine technical efficiency differentials between traditional and improved technologies applied in processing oil palm; and identify its determinants.

\section{MATERIALS AND METHODS}

This study was conducted in Cross River State, Nigeria. Boki Local Government Area was purposively selected for this study due to high involvement in oil palm processing activities. It is located between latitudes $5^{0} 82^{1} \mathrm{~N}$ and $6^{0} 40^{1} \mathrm{~N}$ and longitudes $8^{\circ} 50^{1} \mathrm{E}$ and $90^{\circ} 00^{1} \mathrm{E}$ (Takon et al, 2013); with a humid tropical climate. Both cash and food crops are grown in the area. A multi-stage sampling technique was employed to select 164 processors (61 for traditional; and 103 for improved). Data were collected through structured questionnaire. Stochastic frontier production function was applied to determine the technical efficiency of processors and it's determinants in the area. 
Battese and Coelli (1992) stated the general stochastic frontier production model as:

$\log (\mathrm{Y})=\mathrm{f} \log \left(\mathrm{X}_{\mathrm{i}}\right)+\mathrm{V}-\mathrm{U} \quad$ - - - - 1

The Cobb-Douglas stochastic frontier production function used for analysis is stated in the form:

$\ln \mathrm{Y}=\ln \beta_{\mathrm{o}}+\beta_{1} \ln \mathrm{X}_{1}+\beta_{2} \ln \mathrm{X}_{2}+\beta_{3} \ln \mathrm{X}_{3}+\beta_{4}$ $\ln \mathrm{X}_{4}+\beta_{5} \ln \mathrm{X}_{5}+\mathrm{V}_{i t}-\mathrm{U}_{i t}-\cdots-2$

Where:

$\mathrm{Y}=$ Quantity of palm oil processed (litres);

$\mathrm{X}_{1}=$ Labour (man hour);

$\mathrm{X}_{2}=$ Quantity of fresh fruit (kilogramme);

$\mathrm{X}_{3}=$ Processing period (days);

$\mathrm{X}_{4}=$ Depreciation cost (Naira);

$\mathrm{X}_{5}=$ Other variables cost (water, transport, fuel, loading, offloading, security, storage) (Naira);

$\beta_{0}=$ Constant term;

$\beta_{1}-\beta_{5}=$ vector of the coefficients for the associated independent variables in the production function;

$\mathrm{U}_{i t}=$ one sided component, which captures deviation from frontier as a result of inefficiency of the firm; and

$\mathrm{V}_{i t}=$ effect of random stocks outside the processors control, observation and measurement error and other stochastic (noise) error term

To obtain the determinants of technical efficiency of processors, a regression of the value of inefficiency from the model against some socio-economic factors of the processors was used. Battese and Coelli (1995), expressed the technical inefficiency starting with the frontier production function

$\mathrm{Y}_{i t}=\exp \left(\mathrm{X}_{i t} \beta+\mathrm{V}_{i t}-\mathrm{U}_{i t}\right) \quad---3$
Where:

$$
\mathrm{U}_{i t}=\mathrm{z}_{i t} \delta \delta+\mathrm{w}_{i t} \quad---4
$$

Where:

$\mathrm{W}_{i t}$ is the random variable which is defined by the truncation of the normal distribution with zero mean and variance, such that the point of truncation is $-\mathrm{z}_{i t} \delta \delta$, that is, $\mathrm{W} \geq \mathrm{z}_{i t}$ $\delta \delta$. These assumptions are consistent with $\mathrm{U}_{i t}$ being a non-negative truncation of the $N\left(\mathrm{z}_{\mathrm{it}} \delta\right.$ $\delta, \sigma \sigma)$ distribution (Battese and Coelli, 1995). Explicitly, the inefficiency model is expressed as:

$\mathrm{U}_{\mathrm{i}}=\delta_{0}+\delta_{1} \mathrm{Z}_{1}+\delta_{2} \mathrm{Z}_{2}+\delta_{3} \mathrm{Z}_{3}+\delta_{4} \mathrm{Z}_{4}+\delta_{5} \mathrm{Z}_{5}+\mathrm{W}_{i t}$

Where:

$\mathrm{U}_{\mathrm{i}}=$ value of individual processors technical inefficiency;

$\mathrm{Z}_{1}$, = years of experience of the processor (years);

$Z_{2}$, = level of education of the processor (years);

$Z_{3}$, = duration of membership of processing association (years)

$Z_{4}$, $=$ access to credit (dummy; $1=$ yes, $0=$ otherwise);

$Z_{5}$, $=$ access to extension contact (dummy; $1=$ yes, $0=$ otherwise); and

$\mathrm{W}_{i t}=$ as earlier defined in equation 4

These variables are included in the model to indicate their possible influence on the technical efficiency of the processors. The variance of the random error $\sigma^{2} \mathrm{v}$ and that of the technical inefficiency effect $\sigma^{2} u$ and the overall variance of the model are related as follows: 


$$
\begin{array}{ll}
\sigma^{2}=\sigma^{2} \mathrm{v}+\sigma^{2} \mathrm{u} & ----6 \\
\gamma & =\sigma^{2} \mathrm{u} / \sigma^{2}
\end{array}
$$

Equation (6) measures the total variation of production (output) from the frontier which can be attributed to technical efficiency (Battese and Corra, 1977). The $\sigma^{2}$ and $\gamma$ $\gamma$ coefficients are the diagnostic statistics that indicate the relevance of the use of the stochastic frontier function and the correctness of the assumptions made on the distribution form of the error term. The $\sigma^{2}$ indicates the goodness of fit and the correctness of the distributional form assumed for the composite error term. The $\gamma \gamma$, lies between 0 and 1 ; and indicates that the systematic influence that is unexplained by the production function is the dominant source of random error.

\section{RESULTS AND DISCUSSION}

\section{Technical Efficiency}

Results on technical efficiencies between traditional and improved oil palm processing technologies users are presented in Table 01. The result shows that the generalized likelihood ratio statistics exceeded the critical chi-square (Table 02). Therefore, the Cobb-Douglas functional form is an adequate representation of the data. The gamma statistics indicate that $81 \%$ and $98 \%$ of the changes in the output of oil palm processing using traditional and improved technologies respectively are attributable to processors inefficiency factors. The result revealed that technical inefficiency effects were present in processing oil palm using the two technologies. The $1 \%$ significant level of these results indicates the presence of one-sided error component, $v_{i}$ in the model specified. Due to the presence of this one-sided error component, the traditional response function estimated by the Ordinary Least Square (OLS) cannot adequately represent the data, thus, the use of the stochastic frontier function estimated by the Maximum Likelihood Estimation procedure is adequate.
The significant values of sigma-square $\left(\sigma^{2}\right)$ for the two groups of processors indicate the correctness of the specified assumption of the distribution of the component error terms.

Labour $\left(X_{1}\right)$, fresh fruit $\left(X_{2}\right)$ and other variables cost $\left(\mathrm{X}_{5}\right)$ were positively signed for traditional and improved technologies. The positive effect implies that a 1 unit increase in the variable will lead to an increase in output of palm oil processed. The signs of labour and fresh fruit agreed with a priori expectation. If labour used and quantity of fresh fruit used for processing increased; the quantity of palm oil processed would increased as well. On the other hand, other variables cost (transportation, loading and offloading, fuel, water, security and storage) processing elasticities were not as expected. The positive signs could be as a result of high charges incurred due to poor infrastructural availability which include; bad roads, far markets, poor storage facilities and other amenities.

Processing period $\left(\mathrm{X}_{3}\right)$ had negatively signed estimated coefficients. This is in line with the expectation, as the number of days for processing oil palm increases, palm oil output decreases by the value of the coefficient of the variable. Onwubuya (1997) stated that delay in the time interval between harvest and final output may render the quality and quantity of red oil produced low; hence, reduces the net returns from the final output. Also, Depreciation cost $\left(\mathrm{X}_{4}\right)$ estimated coefficient for traditional technology users' was positively signed, while that of the improved technologies was inversely related to palm oil output. The signs indicate that as depreciation on fixed cost for oil palm processing with traditional technology increases, quantity of palm oil processed increases. This is against $a$ priori expectation. Whereas, depreciation on improved technology fixed items is correctly sign implying that as depreciation increases, quantity of oil output decreases. This could be attributable to the wear and tear of the machines which may lead to loss of palm 
oil during processing. A similar result of a negative depreciation value was obtained by Aburime et al. (2006).

\section{Technical efficiency Determinants}

The determinants of technical efficiency presented in Table 1, revealed that processing experience $\left(Z_{1}\right)$, level of educational $\left(Z_{2}\right)$ and access to extension contact $\left(Z_{5}\right)$ coefficients were negatively signed for traditional and improved methods of processing oil palm, indicating positive effect on technical efficiency. The implication is that, processors with longer years of experience, higher educational level and access to extension contact tend to be more technically efficient than those with fewer years of experience, lower educational level and had no access to extension contact. It is very plausible that, processors with considerable years of education respond readily to effective decision making in agriculture. The analysis is in line with the notion that public investment geared to improve the provision of managerial support and dissemination of information to agrarian society via extension programs, or other forms of non-formal education, is likely to lead to higher levels of efficiency.

Table 01: Maximum likelihood estimate (MLE) of frontier production function for Traditional and Improved oil palm processing technologies

\begin{tabular}{|c|c|c|c|c|c|c|}
\hline \multirow{2}{*}{ Variables } & \multicolumn{3}{|c|}{ Traditional } & \multicolumn{3}{|c|}{ Improved } \\
\hline & Coefficient & SE & T-ratio & Coefficient & SE & T-ratio \\
\hline \multicolumn{7}{|l|}{ General model } \\
\hline Constant $\left(\beta_{0}\right)$ & 0.634 & 0.182 & $3.483^{* * *}$ & 3.602 & 0.363 & $9.923^{* * *}$ \\
\hline Labour $\quad\left(\beta_{1}\right)$ & 1.625 & 0.886 & $1.834^{*}$ & 0.111 & 0.027 & $4.111^{* * * *}$ \\
\hline Fresh fruit $\left(\beta_{2}\right)$ & 0.861 & 0.090 & $9.567^{* * *}$ & 2.261 & 0.440 & $5.138^{* * *}$ \\
\hline Processing period $\left(\beta_{3}\right)$ & -2.019 & 0.963 & $-2.096^{* *}$ & -0.314 & 0.091 & $-3.451^{* * *}$ \\
\hline Depreciation $\left(\beta_{4}\right)$ & 0.101 & 0.405 & 0.249 & -0.478 & 0.447 & -1.069 \\
\hline Other cost $\left(\beta_{5}\right)$ & 0.207 & 0.158 & 1.313 & 0.128 & 0.056 & $2.284^{* *}$ \\
\hline \multicolumn{7}{|l|}{ Inefficiency model } \\
\hline Constant $\left(\mathrm{Z}_{0}\right)$ & -0.273 & 0.221 & -1.233 & -0.578 & 0.109 & -0.530 \\
\hline Processing exp. $\left(\mathrm{Z}_{1}\right)$ & -0.274 & 0.023 & $-11.915^{* * *}$ & -0.312 & 0.108 & $-2.889^{* * *}$ \\
\hline Level of Educational $\left(\mathrm{Z}_{2}\right)$ & -0.857 & 0.752 & -1.139 & -0.781 & 0.136 & $-5.743^{* * *}$ \\
\hline Association $\left(Z_{3}\right)$ & 0.509 & 0.045 & $11.311^{* * *}$ & -3.670 & 0.621 & $-5.909^{* * *}$ \\
\hline Access to credit $\left(Z_{4}\right)$ & 1.572 & 0.145 & $10.830^{* * *}$ & 1.419 & 0.186 & $7.629^{* * *}$ \\
\hline Access to extension $\left(Z_{5}\right)$ & -3.644 & 0.317 & $-11.474^{* * *}$ & -0.963 & 0.360 & $-2.675^{* * *}$ \\
\hline \multicolumn{7}{|l|}{ Variances } \\
\hline Sigma-squared $\left(\sigma^{2}\right)$ & 0.348 & 0.100 & $3.480^{* * *}$ & 0.663 & 0.100 & $6.630^{* * *}$ \\
\hline $\operatorname{Gamma}(\gamma)$ & 0.808 & 0.067 & $12.059^{* * *}$ & 0.983 & 0.061 & $16.114^{* * * *}$ \\
\hline Log likelihood function & 67.102 & & & 96.657 & & \\
\hline LR test & 9.590 & & & 10.340 & & \\
\hline
\end{tabular}

Source: Computed from computer print-out $* * *$ and $* * *=$ significant at $10 \%, 5 \%$ and $1 \%$ level of probability respectively. $\mathrm{SE}=$ Standard Error

Table 02: Generalized likelihood ratio test of hypothesis for parameters of the Stochastic Production Function

\begin{tabular}{llccl}
\hline Null Hypothesis & \multicolumn{2}{c}{ Log likelihood } & Critical & Decision \\
& Traditional & Improved & ${ }^{2}(1 \%)$ & \\
\hline $\mathrm{H}_{\mathrm{o}}: \gamma=0$ & 67.10 & 96.66 & 18.48 & Rejected: $\mathrm{H}_{\mathrm{o}}$ \\
\hline
\end{tabular}

Source: Computed from the computer print-out 
Membership of Association $\left(Z_{3}\right)$ coefficient was positive for traditional technology users implying that it has negative effect on technical efficiency. This suggests that processing efficiency would be lowered the longer traditional processors stay in association. Though, this agrees with the findings of Shehu et al. (2010), but does not agree with the expectation because belonging to association should enhance efficiency among processors as association serve as a medium for information exchange that can improve processing. Whereas, improved technologies users had a negative sign for association membership, implying that processors who have stayed as members of the association are more technically efficient in oil palm processing. Access to credit $\left(\mathrm{Z}_{4}\right)$ had positive coefficient for the two oil palm processing technologies. The positive signs recorded imply that, processors who have access to credit are more inefficient than those who do not have. This could be as a result of untimely access of the credit which may lead to diversion of credit to other non oil palm processing activities. If credit is invested into a production enterprise, it is expected that it should lead to higher level of output, but in case the credit is not accessed on time, it may, more often than not, lead to misapplication of funds. Hence, the expected impact of such credit will not be felt on the enterprise. This is in line with Okike et al. (2001) and Bifarin et al. (2010) in their separate findings that receiving credit contributes to farmers' inefficiency.

Only educational level of traditional technology users was not significant, all other included determinants significantly affect technical efficiency of processors at different levels of probability. The insignificant value for level of education for traditional technology users could be because formal training is not needed for traditional processing method. Therefore, significant variables are the determinants of technical efficiency for oil palm processing in the study area.

\section{Distribution of technical efficiencies}

The general distribution of processors' technical efficiency presented in Table $\mathbf{0 3}$ shows that majority (55 percent) of the processors using traditional processing technologies fall between technical efficiency of 41 percent and 70 percent with a minimum of 26 percent, maximum of 98 percent and a mean of 62 percent. Whereas, their counterparts using improved processing technologies were mostly (75 percent) operating at technical efficiency of 71 percent and above with a minimum of 31 percent, maximum of 98 percent and a mean of 81 percent. This means that the existing resources should be harnessed to attain the frontier level. Furthermore, if the average traditional processor in the sample was to achieve the technical efficiency level of its most efficient counterpart, then, the average processor could realize a 37 percent cost savings (i.e., $1-$ [62/98]) while the most inefficient processor will save 73 percent (i.e., $1-[26 / 98])$. On the other hand, for the average improved technologies user to achieve the same technical efficiency position as the most efficient processor, the average processor will be saving 17 percent cost (i.e., 1- [81/98]) while the most technically inefficient improved technologies processor will be saving 68 percent (i.e., 1- [31/98]) of the cost of processing oil palm. 
Table 03: Distribution of technical Efficiencies for Oil palm Processors

\begin{tabular}{|c|c|c|c|c|}
\hline \multirow[t]{2}{*}{ Class } & \multicolumn{2}{|c|}{ Traditional } & \multicolumn{2}{|c|}{ Improved } \\
\hline & Frequency & Percentage & Frequency & Percentage \\
\hline$\leq 20$ & 0 & 0.0 & 0 & 0.0 \\
\hline$>20-\leq 30$ & 4 & 7.14 & 0 & 0.0 \\
\hline$>30-\leq 40$ & 5 & 8.93 & 4 & 3.92 \\
\hline$>40-\leq 50$ & 10 & 17.86 & 8 & 7.84 \\
\hline$>50-\leq 60$ & 11 & 19.64 & 5 & 4.90 \\
\hline$>60-\leq 70$ & 10 & 17.86 & 8 & 7.84 \\
\hline$>70-\leq 80$ & 5 & 8.93 & 14 & 13.73 \\
\hline$>80-\leq 90$ & 5 & 8.93 & 26 & 25.49 \\
\hline$>90-\leq 100$ & 6 & 10.71 & 37 & 36.27 \\
\hline Total & 56 & 100 & 102 & 100 \\
\hline Maximum & \multicolumn{2}{|c|}{97.7} & \multicolumn{2}{|c|}{97.8} \\
\hline Minimum & \multicolumn{2}{|c|}{25.8} & \multicolumn{2}{|c|}{31.3} \\
\hline Mean & \multicolumn{2}{|c|}{62.0} & \multicolumn{2}{|c|}{80.7} \\
\hline
\end{tabular}

Source: Computed from computer print-out

\section{CONCLUSION}

Oil palm processing is a major activity carried out by the people in the area of study as a result of the favourable climatic condition for oil palm production. The technical efficiency indices computed show that the respondents under study have generally not attained the production frontier. This implies that there is a significant potential for the processors to sustainably increase output using the available inputs and existing technologies. Thus, there will be no need to develop new technologies to raise productivity, but, technical efficiency can be increased by increasing the usage of inputs already available. From the findings, the improved oil palm technology users in the study area are more technically efficient than the traditional technologies users. Based on the findings of this study, the following recommendations are made: Adoption of improved technologies for processing oil palm should be encouraged through adequate provision of extension education in the study area; processors should reduce their processing period by embarking on processing of fresh fruit as soon as harvesting is done; and government and concerned organizations should effectively link oil palm processors to available financial institutions for the provision of on-lending facilities in terms of loans and micro-credit on time as well as technical support.

\section{REFERENCES}

Aburime, I. L., Omotesho, O. A and H. Ibrahim (2006). An Analysis of Technical Efficiency of Beekeeping Farms in Oyo State, Nigeria. European Journal of Social Sciences, 4(1):1-8

Aghalino, S. O. (2000). British Colonial Policies and the Oil Palm Industry in the Niger Delta Region of Nigeria, 1900 - 1960. African Study Monographs, 21(1):19-33, January

Agwu, A. E. (2006). Adoption of Improved Oil Palm Production and Processing Technologies in Arochukwu Local Government Area of Abia State, Nigeria. Agro-Science Journal of Agriculture, Food, Environment and Extension, 5(1): 25-35. 
Aliu, A. O. (2010). How to Revive Nigeria's Oil Palm Industry, By NIFOR. Furtune News, Benin City Business Services-Business News. July 14, Available in http://www.nigerianbestforum.com/generaltopics [Retrieved 18 November, 2010].

Ayodele, T. (2010). African Case Study: Palm Oil and Economic Development in Nigeria and Ghana; Recommendations for the World Bank's 2010 Palm Oil Strategy. Initiative for Public Policy Analysis, Lagos, Nigeria. Available in http://www.ippanigeria.org. 1-13 [Retrieved 3 January, 2011].

Battese, G. E. and Coelli, T. J. (1992). Frontier Production Functions, Technical Efficiency and Panel Data: With Application to Paddy Farmers in India. Journal of Productivity Analysis, 3(1-2): 153-169.

Battese, G. E, and Coelli, T.J. (1995). A model for technical inefficiency effect in stochastic frontier production function for Panel Data. Empirical Economics, 20:325-332.

Battese, G. E. and Corra, G. S. (1977). Estimation of a production frontier model: with application to the pastoral zone of Eastern Australia. Australian Journal of Agricultural Economics, 21(3):167-179.

Bifarin, J. O., Alimi, T., Baruwa, O. I. and Ajewole, O. C. (2010). Determinant of Technical, Allocative and Economic Efficiencies in the Plantain (Musa spp.) Production Industry, Ondo State, Nigeria. Proceeding of International Conference on Banana \& Plantain in Africa, Edited by T. Dubois et al. Acta Hort. 879, 199-210

Food and Agriculture Organization Statistical Database (FAOSTAT), (2010). Available in http:// www. faostat.org/site/339/default.aspx. [Retrieved 23 September, 2010].

Heady, E. O. (1982). Economics of agricultural production and resource use. Englewood Cliffs, NJ Prentice Hall, USA.

Nwajiuba, C. and Akinsami, A. (2003). Implication of improved oil palm (Elaeis guinensis) fruit Processing Technologies for Labour and Income among rural households in Imo State, Nigeria. Deutscher Tropentag, Technological and Institutional Innovations for Sustainable Rural Development: International Research on Food Security, Natural Resource Management and Rural Development, October 8-10, 2003. Goettingen, Germany.

Okike, I., Jabbor, M. A., Manyong, V., Smith, J. W., Akinwumi, J. A. and Ehui, S. K. (2001). Agricultural Intensification and Efficiency in West Africa Savannahs: Evidence from Northern Nigeria. Socio-economic and Policy Research Working Paper 33. ILRI, Nairobi.

Oladipo, J. A. (2008). Agro-Industry as Strategy for Rural Development: An Impact Assessment of Nigeria Oil-Palm Industry. European Journal of Social Sciences, 7(1): 75-87

Olagunju, F. I. (2008). Economics of Palm Oil Processing in Southwestern Nigeria. International Journal of Agricultural Economics \& Rural Development, 1(2): 69-77 
Onwubuya, I. I. (1997). Oil Palm (Elaeis guineensis JACQ), Development in Nigeria with particular reference to the Southeast Agroecological zone. Invited paper read at the workshop on eco-regional programme for the Humid and Sub-humid tropics of SubSaharan Africa. Imo Concorde Hotel, Owerri, Nigeria, October 6.

Orewa, S. I., Adakaren, B., Ilechie, C.O. and Obulechei, S. (2009). An Analysis of the profitability of using the NIFOR small scale palm oil processing equipment (SSPE). Amarican-Eurasian Journal of Agronomy. 2(3):192-300

Shehu, J. F., Iyortyer, J. T., Mshelia, S. I. and Jongur, A. A. U. (2010). Determinants of Yam Production and Technical Efficiency among Yam Farmers in Benue State, Nigeria. Journal of Social Sciences, 24(2): 143-148

Takon, T. J., Amalu, T. E. and Okpara, D. E. (2013). Assessment of Local People's Attitude Towards Natural Resource Conservation in Boki Local Government Area of Cross River State, Nigeria. Research Journal in Organizational Psychology \& Educational Studies 2(2) 60-66

Ugwu, D. S. (2009). Problems and Prospects of Commercial Small and Medium Scale Cocoa and Oil Palm Production in Cross River State, Nigeria. Journal of Applied Sciences Research, 5(7): 827-832

Vogel, J. H. (2002). A Palm oil mill in Oyo state, a draft proposal for Private Venture, Prepared for Government of Oyo State, Ibadan, 1-10.

World Rainforest Movement (WRM), (2000). Nigeria: Malaysian corporation to invest in palm oil production. WRM's Bulletin No. 41, Available in http//www.wrm@wrm.org.uy/bulletin/41.html\#Nigeria. [Retrieved 3 October, 2010]

World Rainforest Movement (WRMs), (2001). Nigeria: Palm oil deficit in a traditional palm oil producing country. WRM's Bulletin No. 47, Available in http//www.wrm@wrm.org.uy/bulletin/47.html\#Nigeria. [Retrieved 3 October, 2010] 